\title{
1. Crisis of capitalism
}

A reform, or revolution even, is needed of the economy as a system and economics as a discipline. That is not a luxury but a political emergency. The need for it is evident from present clashes between economics and society. This chapter offers an elaboration of that need: the symptoms. Then follows the diagnosis: what is going wrong, and the need for therapy: a new economics. Next, an elaboration of how the economy really works, in different industries. And then, the therapy: a proposal for a new economics, in fact present economics stood on its head.

\section{Economic value}

I am not going to claim that economics is entirely wrong, and I continue to use elements from it. Society has much to be grateful for in the economy, in prosperity and employment. Markets are indispensable for that. If it works well, it goes as follows.

Businesses borrow money to invest in knowledge, tools, machines, materials and competence, to develop and produce products that society needs. They make a profit, from which they repay the loans and further invest, and thus create 
employment and growth. In practice it often does work like that, but increasingly it does not.

The demand for products is inflated with advertising, with an appeal to greed and insatiability. Production and distribution cause environmental damage that is not included in the price of products. Profits are not always spent on production and development, but are regularly used to buy other firms to achieve profit growth, without improving those firms or products. Thus, a 'hedge fund' buys a firm with borrowed money, imposes a fee, takes the firm off the stock market, pays the loan and fee from selling part of the firm, firing staff, or economizing on wages or benefits, or on research and development. This increases the short-term profitability of the firm, which raises its share value, and then the firm is sold again on the market. The argument to defend this is that in this way firms are penalized for not fully utilizing their profit potential. But it goes at the expense of the long-term potential of the firm, banking on the market's myopia for the short term, profit in the next quarter.

Sometimes there is a lack of market dynamics, but increasingly also an excess. The market is not to be set aside, but to be set right. Economic thought has its value, up to a point, but has encroached too far beyond the economy, in an ideology that is corroding society. I do not want to abolish economics but to stand it on its head, in a different approach that on crucial points is its opposite. 


\section{Political costs}

Often, what runs aground in society is not a matter of evil intent but of a way of thinking that had good reasoning but lost its bearings, became myopic, and has congealed in perverse systems of thought and action from which it cannot disentangle itself. The thinking becomes an ideology, of which one cannot see, or cannot admit, that it is an ideology. And it needs that blindness for it to work.

This yields what I call 'system tragedy'. The advocates are so entangled in the system that they simply do not see what is wrong with it, but are willing to explain it to the opponents one more time. And if that does not clinch it, the opposition is in a plight of the dumb. The protagonists and profiteers of the system then are aggrieved that one is not grateful to them and does not hold them in esteem. Others, taken up in the system, get entangled in roles and positions with which they disagree but which they cannot afford to refuse, for fear of loss of position, recognition or income until the bomb bursts.

In present economic thought concerning society, the myopia is that one sees only the economic costs and revenues of the conduct of firms. One gives insufficient regard to the political costs of pollution and dodging its regulation, the lobbies of large firms, excessive salaries and bonuses, subsidies on location and on energy, and tax dodges, and all that under the threat to move employment 
abroad if they do not get their way. A substantial part of politics apparently is blind to the political costs, or surrenders to the arm twisting involved.

The legitimacy of business lies in the satisfaction of needs in society; preservation of nature is such a need and if business does not satisfy it, it is renouncing its task.

Where are those political costs? They lie in the rise of populism, the uprising of the 'yellow vests', kindled by partly justified grudges over unequal rights and incomes, and the favours given to large firms and shareholders at the expense of the poor, erosion of expenditure on care and education, and of reward, security, quality, continuity and conditions for labour.

Socialists also have let themselves be seduced by the economic imperative of the 'supply side', i.e. business. 'It's the economy, stupid', was the motto, on the left and the right. One is getting worried by populism but continues to provoke it with economic and political indecencies. With their 'third way', Bill Clinton in the US, Tony Blair in the UK, Gerhard Schröder in Germany and Wim Kok in the Netherlands took a turn to the right, in surrender to globalization. To be fair, the negative effects this would have were not clear then. Now they are, and one can no longer close one's eyes to them. Here I use a definition of the left from Stephanie Mudge (2018): 'Representation of those who are otherwise not represented'. That concerned the poor and the excluded, and now also concerns refugees. 
The problem is not only one of large multinationals, but also of other areas of misuse of power, as in professions that exert a monopoly of knowledge or a cartel to enforce excessive remuneration, such as medical specialists. There, one can say, there is not too much but too little market dynamics.

\section{Populism}

Populism demonstrates growing dissatisfaction of the people, and exploits that for electoral gain. Part of the grudge lies in the justified suspicion that the people carry the burden while especially large, multinational corporations are let off the hook. And, indeed, government goes easy on those out of fear that otherwise they will take their employment elsewhere. That is a genuine problem. In fact, national government is not up to matching the power of those companies, is not in a position to counter them on its own. There is a solution for that, in bundling powers of nations, in the EU, for example, but then populists are against that. They exploit the frustration but obstruct the solution.

However, next to economics there is much more at stake. Is populism a shout for individualism, the citizen at the centre, or the opposite, a call for restoration of community, the social? Such community, with values that are shared to some extent, yields a buffer against uncertainty, on which one can fall back in times of adversity. 
Such opposition between individual and community is only imaginary, since the individual is rooted in the social, and that is precisely what economics has lost sight of, or never had in sight. And the social is rooted in the local. That is one of two reasons for the craving for nationalism: restoration of a sense of local roots.

One of the strongest bonds, arising from evolution, is that of kin. The more closely people are genetically related, the more sacrificing and altruistic they are, as with parents to their offspring, siblings, cousins, etc. The bonding strength of kin terminology, of 'brotherhood', 'family', 'blood', etc. may be adopted, hijacked, so to speak, in 'pseudo-kin', even when relations are hardly genetic. Examples abound: 'brotherhood' among soldiers, soccer fans, motor clubs, gangs. And in this way ethnic divisions creep in, where appearance, colour and culture are connected to kinship.

Another source of nationalistic prejudice, not arising from genetic commonality but often allied with 'pseudo-kin', lies in 'parochial altruism': the human being has a deep suspicion, probably anchored in genes shared universally, against outsiders, to be recognized in different appearance, religion and habits. That has been amply studied in social science. Next to a drive for self-interest and survival the human being has an instinctive drive for recognition and being valued in a community, and is even willing to make sacrifices for others for this. ${ }^{1}$ That is the good news. The bad 
news is that this is accompanied by suspicion of and discrimination against outsiders. And that was needed, in evolution, to protect altruism within the group from exploitation by invading outsiders with different genes, who would otherwise get the upper hand, competing away the altruistic genes. That is what lies beneath the repulsion towards refugees.

The conclusion is not to give in to this prejudice but to better combat it, and make an effort to integrate outsiders so that they are felt to belong to one's own group. Nothing works better for that than to include them in joint activities, in a shared fate, in taking part in work and education. Then immigrants turn out to be human. Then they become colleagues.

People belong to different in-groups, in communities, jobs, professions, memberships, etc. and someone who 'belongs to them' in one context may 'belong to us' in another. This multiplicity is good news, since prejudice in one context may be side-tracked with commonality in another. Robert Sapolsky (2019) quotes an example: 'During WWII .... A British officer and his prisoner, a German officer, shifted categories of enmity into something resembling a friendship that lasted decades when they discovered by chance that they shared a love of Greek classics'.

Next to populism, is there no other resistance to excesses of capitalism? The 'Occupy Wall Street' movement protested, most of all, against the misconduct of banks, but it has since evaporated. The 
movement on purpose did not choose the parliamentary path of developing a political party. As a result it did not muster political power. Recently, there has been a rise, in France, with some spread to other countries, of the 'yellow vests', but that also appears to be dissipating due to a lack of leadership and focus.

\section{What liberalism?}

How was the connection between the individual and the social and the local lost? There, liberalism went off the track. It began well but lost its bearings. But what liberalism are we talking about?

'Liberalism' is an ambiguous notion. A leftist form of it recognizes the communal and social, a rightist form emphasizes the individual and its own responsibility. After World War II, there was a period when attempts were made to balance the two. But from the 1970s it took a right turn, in 'neoliberalism'.

One meaning of liberalism is also that of liberal, constitutional democracy. That does not only include free elections. Illiberal, autocratic regimes, such as those of Putin, Erdogan and Orban, claim those, though in practice in elections the opposition is hampered, in access to the media and preparation of the elections. In any case, elections do not suffice. It is also a matter of equality under the law, rights for minorities, freedoms of speech, association and religion, and separation of powers 
(of government, parliament and the judiciary). Authoritarian regimes dodge those.

Autocratic regimes flourish on seduction of the people by the charismatic leader who claims to listen to his/her people and to represent them directly and to be their embodiment, making parliament superfluous. The decisiveness of the leader stands in contrast to the bumbling of democracy, which can only arrive at delayed and watered-down decisions, that at the fall of government have to be redone all over again in a slightly different direction. Its strength lies precisely in that, since in the democratic process of oversight and journalistic investigation elites do not get the chance to buttress themselves as infallible and irreplaceable. The authoritarian leader can do that and deflect criticism onto some scapegoat, such as a criminalized opposition or foreign power, or apostate, or refugees.

A deeper background of democracy arises from the insight, in the philosophy of knowledge, that the notion of a single, univocal truth is problematic, an illusion, and mankind requires a variety of views, from different, contrasting perspectives.

Liberalism more widely arose in the late 1700s, and there had a leftist load, directed against the rule of nobility and monarchy, that erupted in the French Revolution. Later, in the late 1800s it obtained the meaning of social reform - in the US in the 'New Deal' of Franklin Roosevelt in the 1930s. That developed into the application of the ideas of Keynes, in the management 
of demand with public spending to maintain economic growth and employment. That went on until in the 1970s, with the occurrence of persistent 'stagflation': inflation combined with low growth and high unemployment. That was taken to contradict Keynesianism, though some pointed at shocks in the price of oil as the cause.

Then economic thought made a turn of 180 degrees. Not the Keynesian fiscal policy of government expenditure, but the monetary policy of managing the quantity of money, promoted by Milton Friedman, for the benefit of markets. Demand was no longer central, but the supply of firms in markets. Where in Keynesianism government manipulated the market, now the market manipulated government. Rising unemployment was no longer attributed to low government spending but to high wages. The turnaround was presented as liberation from a leftist ideology, to be replaced by the objective truth of the market, in 'shedding ideological feathers'. That is equally an ideology but one in denial of justice. To work, ideology must be presented as objective truth, here of markets. People do not let themselves be guided by a narrative that is admittedly an invention.

Attention turned primarily to international and financial markets, with a growing influence of financial institutions. Then, in the 1980s, neo-liberalism obtained a rightist connotation, becoming synonymous with 'libertarianism', the ideology of markets that only work in the absence of government 'meddling' in 'laissez faire'. 
There is a 'neoliberalism index' that scores political programmes on four factors: own responsibility, labour as a market value, fewer protective social measures and a greater presence of professions than blue-collar labour, the poor and unemployed. That index increased notably among leftist parties; among rightist parties it was already high (Mudge, 2018, pp. 60, 61). In the ideas of the 'third way', of Clinton in the US, Blair in the UK, Schröder in Germany and Kok in the Netherlands, the left moved along in a turn to the right, partly from the perceived need to give an answer to the rise of Reagan in the US and Thatcher in the UK.

Later, markets will be discussed extensively. I will defend the paradoxical thesis that markets go too far as well as not far enough. The market is an important part of the problem but also of the solution. I will unravel where one lies and where the other, and how to deal with that.

Capitalism has not only derailed in an excess of markets, where they are not desirable, and from lobbies of large firms, but also because large firms themselves obstruct markets, in monopolies and oligopolies, or dodge the necessary oversight and regulation where markets are desirable.

\section{Locality and flexibility}

Back to the grounds for populism. The human being derives its identity from personal interaction, which flourishes best in local contact of some duration. Some time is required to get to 
know each other and build trust. In other words, the human being requires a sufficient degree of community, with a certain shared ethic. I do not want to idealize communities. The most violent derailments of intrigue, hatred, envy and feuds of revenge can arise there, precisely because people are tied together. There must be room for entry and exit, and contacts outside the community, for fresh ideas and to prevent rust and stickiness.

People used to find community in religious ties and social bonds of neighbourhood, school, sport, etc. and also in a job, in a firm, often in teams, and after work in the pub together. For many lower educated people both sorts of connections have disappeared. Communities were broken up by increase of scale, and concentration of work outside communities, departure of work to lower wage countries, and razing of building development for roads, offices and shopping malls, and now what remains is perceived to have priority for refugees. The higher educated and more mobile people found community in the larger firms or professional associations that remained. ${ }^{2}$ But that also is crumbling in individualization of work and shorter periods of employment.

With arguments of economy of scale, Western multinationals enticed developing countries, in Africa, South America and Asia, to let the foreign corporations exploit their resources of land (agriculture), primary goods (oil, minerals, diamonds) and cheap labour (in clothing, electronics) and add value to them and generate profits not locally 
but in their own countries. Small-scale, labourintensive local activities in farming and artisanship were seen as backward and inefficient, and in a narrow economic perspective they were, but they were viable in community-based collaboration, in sharing resources and activities (seeds, ploughing, harvesting, training) and thus distributing costs and risks. Those were pushed aside, and people flocked to cities where they supplied cheap labour under poor working conditions, to the profit of the multinationals.

The dominant stream of economic thought had no eye for all this. On the contrary: the central tenet was that of 'comparative advantage' and maximal flexibility: locally one should focus on where one was relatively resourceful, and other things were to be obtained in trade with others. Labour and capital should not be locally tied but maximally flexible, to move to where its revenue was highest. Comparative advantage was to the advantage of the developed countries, while at the time when they were not yet developed themselves they closed off their markets in order to get a chance to develop (Stiglitz, 2002).

Local roots are seen as rigid and that, the suggestion is, is always bad. That is the rhetoric of maximum flexibility. But often that is counterproductive, also from a purely economic perspective. That applies both for local roots and businesses as places. It is good for both business and workers to invest in knowledge, skills and relations that are specific, and have some 
continuity, for the firm. For the firm because it yields speciality products, with higher profit margins, and for workers because it lends more depth to the job. Such investments require some continuity of job and teams, otherwise those investments will not be made, and that yields loss of quality, next to the fact that some continuity of work is more pleasurable because it gives the opportunity for relations of collaboration. So, it should not be about maximum but about optimal flexibility: the sufficient duration of location without yielding rigidity.

\section{Identity}

In present society and public debate, identity plays an important role. In populism this means especially national identity: in Europe as JewishChristian, or based on the Enlightenment, or on a Romanticist sense of being a unique people. But people also seek identity in their place in society: as feminist, LGBT, scientist, or motor rider. What is the meaning of 'identity'?

There is individual identity ('who am I?') and collective identity ('who are we?'). There is also categorial identity ('where do I/we belong?') and existential identity ('how to we experience ourselves?'). For the individual, existential identity is personal identity. For the group it is cultural identity. Existential identity is connected with questions such as 'what do I/we want?', corresponding values, and the question 'how do I/ 
we think?'. Individual identity is connected with collective identity. One can hardly be part of a group that is at odds with who one is and what one thinks and does, and collective identity contributes to the formation of individual identity.

Individual identity is an intriguing notion. It suggests that in having that identity one is identical to oneself, remains the same with it. But the self is not constant, and not unambiguous. It is multiple and shifts in time, though it has a certain stability, if all is well. Where does that come from? From the body. ${ }^{3}$

Survival of the body requires sufficient coherence and stability of metabolic processes. Those processes yield mental representations in the brain which guide those processes. 'Representation' may not be the right term here. That suggests a mirror image, but intended here is the meaning of 'reproduction', a process of re-enactment rather than mirroring. There is interaction between the formation of those representations and action. Mental representations guide action and are formed in it. If in that process there was insufficient coherence and stability, the body could not survive.

Here I build on a philosophical tradition of pragmatism, with American roots (with the philosophers Peirce, James and Dewey), and connections or similarities among some European continental philosophers (Wittgenstein, in his later work, and Heidegger).

One develops a character and personality, along a path of life, as a totality of attitudes, 
response and conduct, in interaction with the physical and social environment. The individual literally stands or falls with coherence in the body. Without body there is no identity, and in death we lose it. In sum: in the body all impressions, movements and experiences come together. Those form dispositions, impulses and ideas on the basis of experience, and they are tied to the body, along a unique path of life.

If indeed the self is in ongoing development, then what is authenticity, truth to one's 'real' self? Where in time does that lie? How can one be true to something that is in development and furthermore one does not know perfectly? The idea of a self as something given beforehand that manifests itself invariantly is not only unrealistic but also, in my view, scary. Then one is condemned to an original self. Then authenticity perhaps is more that one commits oneself to utilize the opportunity to develop an identity, in the realization of potential and development of new potential, in interaction with one's environment.

In a recent book Francis Fukuyama (2018) claimed that personal identity is oriented towards recognition, to be noticed and appreciated, which he traced back to the ancient Greek notion of 'thymos', used, among others, by Plato. I see that differently. Thymos is the urge for action, to manifestation of the self in the world. That does not by definition require recognition. That would reduce all striving for excellence, in entrepreneurship, sports, science, health care, craftmanship, politics, 
etc. to a form of narcissism. It can also be about its intrinsic value, as giving meaning to life and developing and employing one's talents.

\section{Thinking in boxes or relations}

What is collective identity? The human being has a tenacious tendency to think in terms of boxes in which one may reside, or not. You are 'in love', 'in order', 'in conflict', 'in a position', 'in defence', etc. You cannot be both inside and outside a box - hence no two passports. And those boxes harbour an essence that you only have inside it, not outside.

But in fact, one is inside different boxes at the same time: in one's neighbourhood, in a job, in a profession, municipality, and yes, also in a country. That is paradoxical: how can you be in different boxes at the same time? Which is the box 'that really matters?' In this way thought is forced in the wrong direction. The box apparently is not a good metaphor.

An alternative is to think in terms of relations, and patterns of them, in networks. You cannot simultaneously be in different boxes but you can be in different networks. And then you have more or less overlapping networks with others, in a neighbourhood, family, friends, job, profession, etc. And then, what is more important: the neighbourhood, family, friends, province, nation, or Europe, say? You are in all at the same time, and there is nothing wrong with that. Which network 
is salient depends on the context. Is it about work, personal relationships, where you live, profession, religion, vacation, or home country?

And then a problem arises for the lower educated and less mobile people, who have lost their local networks of neighbourhood, church, pub and job, and received no replacement of networks in profession and globalization. It is no coincidence that they crave especially for the preservation of values of family, community and religion. They cherish the metaphor of the box for lack of networks, falling back on the intuitions of kinship and the 'in-group'.

Networks vary in their density and in the strength, durability and 'richness', i.e. multiplicity of content, of ties. In many cases ties have become less local and less rich in the sense of less personal and more formal. The content of ties can be material goods, knowledge, communication, reputation, direction, empathy, support, symbols, ritual, etc.

What maintains a network, what is its cement? That is partly economic, in shared interest and mutual complementarity, as in markets. It is also cultural: shared views, understandings, familiarity, values and norms of conduct, habits, style of conduct, etc. Those are mostly tacit, unspoken and taken for granted, requiring no argument until they are lacking. They are backed up with stories of shared history, symbolism, ideology and rituals to maintain and confirm them.

Those vary within a nation, with habitat, family, 
profession, job, education, region, etc. Such identity is primarily local but can to some extent be raised to the national level. What people primarily share, in a nation, is language, the laws that have been made, the underlying legal constitution, with the corresponding legal institutions and legal process. But that one also has, to a lesser extent, in the EU. The nation does not in fact refer to a unique property or essence, but to a shared product.

In his book on identity, Francis Fukuyama wrote of four characteristics of the feeling of forming a people: shared religion, ethnicity, language and democratic governance. Because of the mixing, in the US, of religions and ethnicities, only the last two remained, and for that Fukuyama used the term of 'creedal identity': shared views of how people associate with each other. I adopt that notion, needed in the present mixing of religion and ethnicity also in European societies. It is crucial not to see identity in terms of goals in life, but in terms of how to deal with each other, leaving room for variety in goals. It is not about who we are but about what we do.

An idea has run out of hand of identity, of 'who one is', as connected to a group to which one belongs and with which one identifies: next to religion also feminism, LGBT, environmental activism, white power, being non-white, or having a history in slavery. The recognition of such groups was needed for the recognition of injustice and a striving for emancipation, but that has petrified in 
identification with the group. The problem with it is that it then becomes difficult to negotiate about interests and make compromises on that: claims of identity, of 'who we are', are not negotiable.

According to a rule of thumb, there is a maximum to the size of a group that maintains its coherence on the basis of personal contacts and reputation in a gossip network, of some 150 people. Beyond that one needs either a shared hierarchy or a shared ideology, with corresponding mythology and symbolism.

Hierarchy can arise by concentration of power in central positions in networks. One can also derive identity from a political party or movement, with a political ideology. That counts the more, the more there is loss of networks of neighbourhood, community, church, job, etc., as discussed earlier. A political party is also best seen not as the container of some essence, but as a network of leaders, opinion makers and functionaries (ministers, MPs, local administrators), who contribute to shared ideology, interpretation and style, which can shift in time. There looms the danger of an elite that locks itself up in itself and thereby no longer satisfies the task of representation of an electorate, which can lead to desertion or revolt.

Collective identity is expressed in symbols. The identity that foreigners ascribe to the Dutch is symbolized by windmills, clogs, cheese and, for Americans, the little boy who stuck his thumb in the leak of a dyke, which to the Dutch is totally 
unknown. The nice thing about symbols, and their effectiveness, is that they are subject to a variety of interpretations, which leaves some leeway for variety. In this way, symbols can gesture towards unity while hiding a variety of views. The symbols can also be role models, such as, in the Netherlands, William of Orange, who led the rebellion against Spain in the 16th century, and the soccer player Johan Cruijff. The view of symbols can change. Jan Pieterszoon Coen, the governor of the then Dutch colony of Indonesia, once was a hero but now is a vile colonialist. Symbols are not innocent. They are part of a symbolic order that carries an ideology while at the same time occluding it.

\section{Nationalism}

In view of all this, the re-emergence of nationalism is understandable, as a craving for restoration of the local, the old, shared culture, with its own supposed essence, pseudo kinship and in-group bias. But when you look at what that means, it largely falls apart as loose sand. Is the essence of, say, the Dutch, the 'Jewish-Christian values', the Enlightenment, Romanticism or the classical Greek heritage? Protestantism or Catholicism? Wars have been waged between them. Which side between nobles and slaves, bourgeois and labour, monarchy or republic, city and countryside, high and low education?

Admittedly, nation often goes together with a 
shared language, with exceptions (Switzerland). But there are also dialects, and people can communicate with different languages, at home and abroad. The state is accompanied by laws, but those increasingly, and necessarily, cross borders. Nationalists parade myths of ancient knights and resistance heroes, but on closer inspection they fall apart. And one can equally, perhaps better, identify with the local soccer club.

To an increasing extent, laws and regulations must be supra-national, concerning terrorism, the climate, migration, defence, foreign policy, control of financial markets, media, fake news, hacking, privacy, transport and ICT. That side of globalization is inevitable and beneficial.

\section{Community}

If one wants a return to the local, why not go a step deeper than the national, to municipalities or neighbourhoods, or in other words the 'commons'? Then an 'hourglass shape' arises: more on the supra-national level, less on the national level and more on the local level.

The local level approaches the scale of the original, iconic democracy in Athens, where citizens (admittedly, no women or slaves) entered in discussion with each other on the city square. There one achieves personal contact, gossip and reputation. Admittedly, this can be dominated by demagogues, but that happens on the national level as well. Also, it can derail in clientship. On 
the local level citizens can be involved in 'organic collaboration', policy formation with citizens' councils, election of mayors and council members, and in projects for development and implementation of policy. The rise of local parties has shown the interest in this.

An example is the municipality of Saillans in France, and another the initiative in the English municipality of Frome. ${ }^{4}$ There, citizens, united in the movement of 'independents for Frome', wanted to set up a citizens' council, but they could not bypass the party system in place. They then founded a party with the aim of introducing the system if they obtained a majority. In 2011 they had 17 candidates of which 10 were elected, by which they obtained a majority and introduced their system. The only thing they agreed upon in advance was a procedure for deliberation with citizens, in a 'ways of working'. They showed that it worked, and in 2015 their majority rose to 17 members of the council.

What are the potential problems? Some people do not want to participate, and simply want government to take care of things. Or people drop out because they form an excluded minority. Or participation requires a level of knowledge or abstraction that they do not have. On the local level, that is not a large problem, because it often concerns local spatial planning (roads, playgrounds, bridges) or schools, care, security, or conveniences, for which one does not require higher education to form a judgement. The lower 
educated are no less intelligent, dedicated and socially capable but perhaps are more so.

However, also with local referenda the choices of a majority can violate the rights of a minority. Who oversees that the rule of law is not violated? Perhaps for these reasons there must be a local ombudsman where people can lodge a complaint. How about a possible danger of local clientship, where local bobos rule, misuse their power, and fall into corruption? The chance of that is no less in the present hierarchies of national parties, with deals behind doors, than in the broader, public councils we are dealing with here.

Another potential problem is the following. Decentralization entails local differences, thus inequality of facilities and arrangements. There lies a fundamental political issue: is one prepared to accept such differences? Must a limit be imposed on such inequalities? Where should that be done? I spoke to a mayor who implanted local governance with different outcomes in different parts of the city, and found that people could very well understand that such differences may be in order. Of course, laws remain national, with equality under the law.

A model for the economy that I am pleading for in this book may lie in the African belief and practice, in society and economy, of 'Ubuntu'. That rests on the principle that all human beings are interconnected and inter-dependent. It advocates and perpetuates the values of commonality and reciprocity. Mary Njeri Kinyanjui (2019) 
sums up the business model involved as follows: 'solidarity entrepreneurialism, which encourages individual initiatives in a context of group agency ... reflected in the sharing of transaction costs ... learning from older traders and later mentoring new ones, agreeing to rules that regulate the group, and pooling assets' (p. 121). This yields what from the perspective of mainstream economics and modern corporate capitalism, adopted by the African elites, is derogated as a primitive 'informal economy', but it continues to flourish in local markets of traders and artisans. Evidence for its viability lies in the fact that it has flourished for a long time in history, before the advent of capitalism and colonialism. I haven't studied this field myself, and I hold one important reservation: the expectation that the closer local bonds of kin and solidarity are, the greater the tension between communities and tribes, which may create a lock-in into local communities and contribute to inter-tribe conflict and violence. However, Mary Njeri Kinyanjui presents evidence that in the large markets of traders and artisans in large African cities there is collaboration between tribes, taking care to share and rotate leadership among them. I think this should be given open attention and further investigation.

\section{Banking}

A discussion of the banking crisis and possible solutions cannot be left out here, because it is a 
paragon of how markets can go wrong, but it becomes a bit technical, here and there.

What was going on? The problems began when banks started to provide not only checking and saving accounts but also mortgages and other forms of credit, including shares, and started owning and trading them. Doing that, they fell into the temptation to take too high risks, and to hide them, as in dubious mortgages, and to hive off the risks onto the community, which is forced to rescue big banks when they are about to fail to prevent the system breakdown that would result from their default.

In the aftermath of the crisis of 2008, measures were taken to rein in the banks to some extent. In Europe that had to be done on the supranational, European level, for sufficient clout against the big banks. Among other things, banks must now hold larger reserves against risk, the calculation of risk has been regulated, a bankers' oath was instituted, and bonuses were curtailed. However, the deeper problems have not been solved. There still is the problem that one cannot let big banks default. The director of the G30, ${ }^{5}$ Mackintosh, said: 'If a major international bank once again teeters on the brink of collapse, no one in finance believes they would be allowed to fail'(WRR, 2019, p. 131).

Mid September 2018 the president of the Dutch national bank expressed his amazement and concern that that again banks now claim a yield on investments of 15 per cent. With a riskless interest rate of about zero that can only work 
under excessive risks. There is a solution, in splitting up banks into low-risk public banks for checking accounts and savings, fully backed by the national bank, and banks that offer credit, investment and trade in shares and bonds, which deregulated, must carry their own risks and be allowed to default, at the expense only of owners and shareholders. Such a split was instituted in the US (in the Glass-Steagall act of 1915), but was later abolished under pressures of banking (under President Clinton), instituted again by President Obama and abolished again by President Trump. A similar proposal was recently put to the EU but rejected, for reasons unknown. Recently, in January 2019, in the Netherlands the Scientific Council for Government Policy (WRR) issued a similar proposal. Another proposal was to enhance 'relationship banking', with a role for citizen panels, for oversight and advice, and a representative from customers as member of the supervisory board.

The continuation of misconduct not only concerns banks. After scandals of tamper software in the automobile industry, it was in the news recently that now the same firms are being indicted by the EU for collusion in keeping from the market new systems that clean exhaust gases. The pharmaceutical industry demands exorbitant prices for some medication and claim that this is justified by the high costs of development in relation to the low volume of sales, but they refuse to make the costs of development and production 
transparent so that the claim can be tested. The joint agreement in the industry not to give that information can be seen as a form of oligopolistic collusion. 